\title{
Interplay of writing skill and inquiry-based learning strategy in EFL classroom
}

\author{
Sam Hermansyah ${ }^{\mathrm{a}, 1, *}$, Andi Sadapotto ${ }^{\mathrm{b}, 2}$ \\ ${ }^{a, b}$ Universitas Muhammadiyah Sidenreng Rappang, Jl. Poros Enrekang-Tator, Maccorawalie, Panca Rijang, Kabupaten Sidenreng Rappang, Sulawesi \\ Selatan 91651 \\ 1 syam_hermansyah85@yahoo.com *; ${ }^{2}$ sadapotto.andi@yahoo.co.id \\ * corresponding author
}

\section{ARTICLE INFO}

\section{Article history}

Received 14 December 2019

Revised 4 March 2020

Accepted 24 August 2020

Available online 15 January 202

\section{Keywords}

students

writing skill

Inquiry-based learning strategy

\begin{abstract}
The objective of the study is to improve the students' writing skills through inquiry-based learning strategy of the first-year students of UMS Rappang. It employs collaborative classroom action research. The researcher and the collaborator teacher work together in designing the lesson plan, implementation, and reflection. Each cycle of the study comprises four meetings: three meetings for the treatment, one meeting for the writing test. The data were collected through observation checklists, writing tests, portfolios, field-notes, and the students' writing performance. Inquiry-based learning takes five major steps. First, students answer the questions given by the teachers about a particular topic. Second, students observe the given pictures, objects, and reading texts, and share their ideas about the observation. Third, students take notes of the observation. Fourth, students discuss the results of the observation and do peer editing. Fifth, the students re-read their writing for content and clarity of meaning and produce the final version to be submitted to the teacher. During the process, the students are grouped heterogeneously, regardless of their achievement, so they can interact and help each other. The teacher controls and guides the learning activities.
\end{abstract}

\section{Introduction}

English is a compulsory subject to learn, especially in Indonesia. It covers four skills: listening, reading, speaking, and writing. At secondary schools, the four skills are integrated. However, to organize the activities, an English teacher usually focuses on one or two language skills.

One of the skills to focus on is writing. Similar to other skills, writing is a means of delivering ideas in written form for a particular purpose. Through writing, an individual can explain or describe things to other people, or the readers (Dixon \& Denise, 1983). As a means of communication, writing plays a great role. The significance is evident in the function and contribution to the development of human life. Generally, people can take advantage of good writing, such as finding a job. Besides, students with good writing skills can help them in learning.

Therefore, it is clear that writing is as important as speaking, listening, and reading. In the future, students are expected to be able to write letters, reports, or any other forms of document. Also, they are expected to know the special features of writing, such as punctuation, paragraph development, and others, despite the necessity of speaking English appropriately.

Raimes (1991) stated that writing can help students learn better. Through writing, students are exposed to grammatical structures, idioms, and vocabulary. When they write, they can gain the opportunity to explore the language, to go beyond the classroom activities. In writing, students learn 
to express their ideas and constantly uniquely use their senses. Gere (1992) asserted that writing facilitates learning. It helps learners understand more of what they have learned. After they generate their ideas, underline contradictions, and create a new perspective of a subject, they can demonstrate their learning results.

Writing is a complex process experienced by a writer in exploring their thoughts and ideas, enabling them to do a kind of reflection. The written thought will examine, reconsider, add, rearrange, and change the ideas (Ghaith, 2002).

Sharples (1999) mentioned that writing is a recurring process, and each writer experiences a different thing. Furthermore, writing is the result of thinking, drafting, and revising that require particular skills that sometimes are not naturally developed.

Hence, novice writers need to practice their writing skills. It can involve copying or reproducing material in order to learn the spelling, punctuation, and grammatical features. Students need to write through a variety of grammar practice in a controlled manner. They need to write within a particular framework that includes transforming the ideas, combining sentences, expanding and framing the ideas, and other similar activities.

A writing process starts with a premeditated intention of changing an attitude. The intention is expressed in words. Nevertheless, in expressing the intention, the message may be misunderstood by the readers. Therefore, the sentences must be arranged in such a way to deliver accurate meanings (Reid, 1993). Putting ideas in sentences means telling other people about the writer's mind. Writing is not only about expressing ideas in sentences but also about developing the ideas into paragraphs.

\subsection{Research Problem}

In line with the background, the problem can be formulated as the following. "Can the writing skill of the first-year students of UMS Rappang be improved through inquiry-based learning strategy?"

\subsection{The objective of the Study}

Based on the research problem stated, this research, generally, is intended to improve the writing skill through the inquiry-based learning strategy of students at UMS Rappang.

\subsection{Significance of the Study}

The researchers try to find out how the inquiry-based learning strategy can be used effectively in EFL. It is expected that the research results can: (1) help students solve their problems in writing skills so that they are more active and motivated in learning the writing skill. (2) enrich the teacher's knowledge with the appropriate model of inquiry-based learning strategy applicable in EFL class to improve the students' writing skills. (3) contribute to the school in improving the teaching and learning and in enhancing the quality of education as a whole. The study is intended to find the effectiveness of an inquiry-based learning strategy in the EFL classroom. It is expected that the results will have several contributions. It is expected to help students solve their problems in writing, allowing them to be more active and motivated. Besides, it is expected to enrich the teacher's knowledge of an appropriate model of an inquiry-based learning strategy to improve the students' writing skills. Further, it is expected that the research contributes to the improvement of teaching and learning activities in schools, as well as increasing the quality of education in general.

\subsection{Review of Related Literature}

As mentioned previously, writing skill is one of the language skills to teach in learning a language. In the school context, writing has equal importance with the three others. Writing activities can help students improve their skills. According to Ur (1996), writing is to express ideas, allowing the writer to convey the message to the readers. To help the students, classroom activities can be done in a group discussion, such as in writing a letter or a report.

\section{Research Method}

The study employs collaborative action research (CAR). The researchers collaborated with one classroom teacher of UMS Rappang. The collaboration is to encourage English teachers to teach using inquiry-based strategies. Inquiry-based learning (IBL) is a pedagogical approach that engages learners actively in a knowledge-building process through the generation of answerable questions (Harada \& Yoshina, 2004). It focuses on a particular classroom or a group of students working together in 
addressing an issue or completing a project (Chu, et al., 2017). In other words, the collaborator serves as a practitioner while the researcher an observer. It is to maintain the natural atmosphere of the classroom because the students are accustomed to the teachers. It is expected that the strategy will improve the students' writing skills.

\section{Findings and Discussion}

Table 1. The classification of students writing in cycle 1

\begin{tabular}{cccc}
\hline Score & Classification & Frequency & Percentage \\
\hline $81-100$ & Very good & 2 & $4.5 \%$ \\
$61-80$ & Good & 21 & $47.7 \%$ \\
$41-60$ & Fair & 20 & $45.5 \%$ \\
$21-40$ & Poor & - & 0 \\
$0-20$ & Very poor & 1 & $3.3 \%$ \\
& Total & 44 & $100 \%$ \\
\hline
\end{tabular}

Table 1 shows that the very good category of the score (81-100) is achieved by two students $(4.5 \%)$. While the good category $(61-80)$ is $21(47.75 \%)$, fair (41-60) by 30 students $(45.5 \%)$. No student achieved the poor category, but one reached very poor classification. From the table, it is known that some aspects of the teaching and learning strategies need to be revised and improved. The results lead to the next cycle of the research.

Table 2. The rating percentage of students writing work in cycle 1

\begin{tabular}{ccc}
\hline Classification & Frequency & Percentage \% \\
\hline Successful & 2 & $4.5 \%$ \\
Unsuccessful & 42 & $95.5 \%$ \\
Total & 44 & $100 \%$ \\
\hline
\end{tabular}

From the result of cycle 1, only two students are categorized successful in following the learning process using inquiry-based strategy.

Table 3. The classification of students writing in cycle 2

\begin{tabular}{cccc}
\hline Score & Classification & Frequency & Percentage \\
\hline $81-100$ & Very good & 37 & $84.1 \%$ \\
$61-80$ & Good & 1 & $3.3 \%$ \\
$41-60$ & Fair & 5 & $11.4 \%$ \\
$21-40$ & Poor & 0 & $0 \%$ \\
$0-20$ & Very poor & 0 & $0 \%$ \\
& Total & 44 & $100 \%$ \\
\hline
\end{tabular}

In cycle two, the number of successful categories increased. The students in "very good" classification increased to $37(84.1 \%)$, one student in the "good" category $(3.3 \%)$, five students in fair $(11.4 \%)$, and no student is listed in the "poor" and "very poor" category.

Table 4. The rate percentage of students writing work in cycle 2

\begin{tabular}{ccc}
\hline Classification & Frequency & Percentage \% \\
\hline Successful & 37 & $84.1 \%$ \\
Unsuccessful & 7 & $15.9 \%$ \\
Total & 44 & $100 \%$ \\
\hline
\end{tabular}

From the findings, it is evident the inquiry-based strategy requires the teachers to follow a particular procedure, which includes five steps. First, the teacher designs a challenging learning task, appropriate materials, and interesting media, such as pictures and dolls. Then, students brainstorm the topic they are going to write. Second, the teacher provides the students with several examples of 
writing, of which the language has been simplified according to the students' ability. The models are simple sentences and a short paragraph along with a series of pictures. The teacher explains the model briefly before the instruction. Third, the teacher distributes the pictures and objects to the students. During the process, the students are encouraged to share ideas and make discussion. Fourth, the teacher asks and guides the students to take notes on the investigation conducted in the previous stage. The notes are in the form of a list using simple sentences. Fifth, the teacher asks and helps the students to develop the draft into a short paragraph. Here, the students are invited to share their ideas and correct each other's writing. Lastly, the teacher allows the students to review their draft based on the peer-reviewing, making sure that they write the notes correctly before submitting it.

\section{Conclusion}

It can be concluded that, in general, inquiry-based strategies can improve the writing skills of the first-year students of UMS Rappang. They are actively involved in writing activities. In addition, students are more motivated and enthusiastic to learn English. The strategy has succeeded in building the rapport between the teacher and the students.

Nevertheless, it is suggested that an English teacher having students with similar characteristics to the ones in the present study apply this model as an alternative teaching method. Further, the teacher can introduce the strategy and discuss it in a forum among teachers, such as in-service training, in a workshop, and a seminar. In an academic context, teachers can write an article about the topic for a journal or a newspaper.

\section{References}

Chu, S.K.W., Reynolds, R.B., Tavares, N.J., Notari, M., Lee, C.W.Y. (2017). $21^{\text {st }}$ century skills development through inquiry-based learning. Singapore: Springer.

Dixon, C. N., \& Nessel, D.D. (1983). Language experience approach to reading and writing. New Jersey: Prentice-Hall, Inc.

Ghaith, G. (2002). Writing. Retrieved from http://www.nadasisland.com/ghaith-writing.html\#nature.

Gere, A. R. (1992). Writing and learning. New York: Macmillan Publishing Company.

Harada, V. H., \& Yoshina, J. M. (2004). Inquiry learning through librarian-teacher partnerships. Worthington, $\mathrm{OH}$ : Linworth Publishing.

Raimes, A. (1991). Out of the woods: Emerging traditions in the teaching of writing. TESOL quarterly, 25(3).

Reid, J. M. (1993). Teaching ESL writing. Englewood Cliffs, NJ: Prentice Hall Regents.

Sharples, M. (1999). How we write: Writing as creative design. London: Routledge.

Ur, P. (1996). A course in language teaching: Practice and theory. Cambridge: Cambridge University Press. 